\title{
Predicting Pinus monophylla forest cover in the Baja California Desert by remote sensing
}

\author{
Jonathan G Escobar-Flores ${ }^{1}$, Carlos A Lopez-Sanchez ${ }^{2}$, Sarahi Sandoval ${ }^{3}$, Marco A Marquez-Linares ${ }^{1}$, \\ Christian Wehenkel ${ }^{\text {Corresp. } 2}$ \\ ${ }^{1}$ Centro Interdisciplinario De Investigación para el Desarrollo Integral Regional, Unidad Durango, Instituto Politécnico Nacional, Durango, Durango, México \\ 2 Instituto de Silvicultura e Industria de la Madera, Universidad Juárez del Estado de Durango, Durango, Mexico \\ 3 CONACYT - Instituto Politécnico Nacional. CIIDIR. Unidad Durango, Durango, Durango, México
}

Corresponding Author: Christian Wehenkel

Email address: wehenkel@ujed.mx

The Californian single-leaf pinyon (Pinus monophylla var. californiarum), a subspecies of the single-leaf pinyon (the world's only 1-needled pine), inhabits semi-arid zones of the Mojave Desert (southern Nevada and southeastern California, US) and also of northern Baja California (Mexico). This tree is distributed as a relict subspecies, at elevations of between 1,010 and 1,631 $\mathrm{m}$ in the geographically isolated arid Sierra La Asamblea, an area characterized by mean annual precipitation levels of between 184 and $288 \mathrm{~mm}$. The aim of this research was i) to estimate the distribution of $P$. monophylla var. californiarum in Sierra La Asamblea by using Sentinel-2 images, and ii) to test and describe the relationship between the distribution of $P$. monophylla and five topographic and 18 climate variables. We hypothesized that i) Sentinel-2 images can be used to predict the $P$. monophylla distribution in the study site due to the finer resolution $(x 3)$ and greater number of bands $(x 2)$ relative to Landsat-8 data, which is publically available free of charge and has been demonstrated to be useful for estimating forest cover, and ii) the topographical variables aspect, ruggedness and slope are particularly important because they represent important microhabitat factors that can determine the sites where conifers can become established and persist. An atmospherically corrected a 12-bit Sentinel-2A MSI image with ten spectral bands in the visible, near infrared, and short-wave infrared light region was used in combination with the normalized differential vegetation index (NDVI). Supervised classification of this image was carried out using a backpropagation-type artificial neural network algorithm (BPNN). Stepwise multiple linear binominal logistical regression and Random Forest classification including cross validation were used to model the associations between presence/absence of $P$. monophylla and the five topographical and 18 climate variables. Using supervised classification of Sentinel-2 satellite images, we estimated that $P$. monophylla covers 6,653 \pm 319 hectares in the isolated Sierra La Asamblea. The NDVI was one of the variables that contributed most to the prediction and 
clearly separated the forest cover (NDVI > 0.35) from the other vegetation cover (NDVI < 0.20). Ruggedness was the most influential environmental predictor variable, indicating that the probability of occurrence of $P$. monophylla was greater than $50 \%$ when the degree of ruggedness TRI was greater than $17.5 \mathrm{~m}$. The probability of occurrence of the species decreased when the mean temperature in the warmest month increased from 23.5 to $25.2^{\circ} \mathrm{C}$. Ruggedness is known to create microclimates and provides shade that minimizes evapotranspiration from pines in desert environments. Identification of the $P$. monophylla stands in Sierra La Asamblea as the most southern populations represents an opportunity for research on climatic tolerance and community responses to climate variability and change. 


\section{Predicting Pinus monophylla forest cover in the Baja}

2 California Desert by remote sensing

3 Jonathan G. Escobar-Flores ${ }^{1}$, Carlos A. López-Sánchez ${ }^{2}$, Sarahi Sandoval ${ }^{3}$, Marco A. Márquez-Linares

$4{ }^{1}$, Christian Wehenkel ${ }^{2}$

$5 \quad{ }^{1}$ Instituto Politécnico Nacional. Centro Interdisciplinario De Investigación para el Desarrollo Integral

6 Regional, Unidad Durango., Durango, México

$7 \quad 2$ Instituto de Silvicultura e Industria de la Madera, Universidad Juárez del Estado de Durango, Durango,

8 México

$9{ }^{3}$ CONACYT - Instituto Politécnico Nacional. CIIDIR. Unidad Durango. Durango, México

11 Corresponding author:

12 Christian Wehenkel ${ }^{2}$

13 Km 5.5 Carretera Mazatlán, Durango, 34120 Durango, México

14 Email address: wehenkel@ujed.mx

\section{ABSTRACT}

Background. The Californian single-leaf pinyon (Pinus monophylla var. californiarum), a subspecies of the single-leaf pinyon (the world's only 1-needled pine), inhabits semi-arid zones of the Mojave Desert (southern Nevada and southeastern California, US) and also of northern Baja California (Mexico). This tree is distributed as a relict subspecies, at elevations of between 1,010 and 1,631 $\mathrm{m}$ in the geographically isolated arid Sierra La Asamblea (Baja California, Mexico), an area characterized by mean annual precipitation levels of between 184 and $288 \mathrm{~mm}$. The aim of this research was i) to estimate the distribution of $P$. monophylla var. californiarum in Sierra La Asamblea by using Sentinel-2 images, and ii) to test and describe the relationship between the distribution of $P$. monophylla and five topographic and 18 climate variables. We hypothesized that i) Sentinel-2 images can be used to predict the P. monophylla distribution in 
28 the study site due to the finer resolution (x3) and greater number of bands (x2) relative to

29 Landsat- 8 data, which is publically available free of charge and has been demonstrated to be useful for estimating forest cover, and ii) the topographical variables aspect, ruggedness and slope are particularly important because they represent important microhabitat factors that can determine the sites where conifers can become established and persist. Methods. An atmospherically corrected a 12-bit Sentinel-2A MSI image with ten spectral bands in the visible, near infrared, and short-wave infrared light region was used in combination with the normalized differential vegetation index (NDVI). Supervised classification of this image was carried out using a backpropagation-type artificial neural network algorithm (BPNN). Stepwise multiple linear binominal logistical regression and Random Forest classification including cross validation (10-fold) were used to model the associations between presence/absence of $P$. monophylla and the five topographical and 18 climate variables. Results. Using supervised classification of Sentinel-2 satellite images, we estimated that P. monophylla covers $6,653 \pm 319$ (standard error) hectares in the isolated Sierra La Asamblea. The NDVI was one of the variables that contributed most to the prediction and clearly separated the forest cover (NDVI $>0.35$ ) from the other vegetation cover (NDVI $<0.20$ ). Ruggedness was the most influential environmental predictor variable, indicating that the probability of occurrence of $P$. monophylla was greater than $50 \%$ when the degree of ruggedness TRI was greater than $17.5 \mathrm{~m}$. The probability of occurrence of the species decreased when the mean temperature in the warmest month increased from 23.5 to $25.2^{\circ} \mathrm{C}$. Discussion. The accuracy of classification was similar to that reported in other studies using Sentinel-2A MSI images. Ruggedness is known to create microclimates and provides shade that minimizes evapotranspiration from pines in desert environments. Identification of the P. monophylla stands in Sierra La Asamblea as the most southern 
51 populations represents an opportunity for research on climatic tolerance and community responses to climate variability and change.

\section{INTRODUCTION}

54 The Californian single-leaf pinyon (Pinus monophylla var. californiarum), a subspecies of the

55 single-leaf pinyon (the world's only 1-needled pine), inhabits semi-arid zones of the Mojave Desert (southern Nevada and southeastern California, US) and also of northern Baja California (BC) (Mexico). It is both cold-tolerant and drought-resistant and is mainly differentiated from the typical subspecies Pinus monophylla var. monophylla by a larger number of leaf resin canals and longer fascicle-sheath scales (Bailey, 1987). This subspecies was first reported in BC in 1767 (Bullock et al., 2006). The southernmost record of P. monophylla var. californiarum in America was previously in BC, 26-30 miles north of Punta Prieta, at an elevation of 1,280 m (longitude $-114^{\circ} .155$; latitude $29^{\circ} .070$, catalogue number ASU 0000235), and the type specimen is held in the Arizona State University Vascular Plant Herbarium. This species is distributed as a relict subspecies in the geographically isolated Sierra La Asamblea, at a distance of $196 \mathrm{~km}$ from the Southern end of the Sierra San Pedro Martir and at elevations of between 1,010 and 1,631 m (Moran, 1983) in areas with mean annual precipitation

67 levels of between 184 and $288 \mathrm{~mm}$ (Roberts \& Ezcurra, 2012). The Californian single-leaf pinyon grows together with up to about 86 endemic plant species, although the number of

69 species decreases from north to south (Bullock et al., 2008). annual precipitation levels of less than $150 \mathrm{~mm}$. In fact, seeds of this variety survive well under 
72 shrubs such as Quercus spp. and Arctostaphylus spp., a strategy that enables the pines to widen

73 their distribution, as has occurred in the great basin in California (Callaway et al., 1996;

74 Chambers, 2001), and for them to occupy desert zones such as Sierra de la Asamblea. Despite

75 the importance of this relict pine species, its existence is not considered in most forest

76 inventories in Mexico (CONABIO, 2017).

77 Remote sensing with Landsat images has been demonstrated to be useful for estimating forest

78 cover; the Landsat- 8 satellite has sensors ( 7 bands) that can be predicted vegetation attributes at a

79 spatial resolution of $30 \mathrm{~m}$ (Madonsela et al., 2017). However, the European Space Agency's

80 Copernicus program has made Sentinel-2 satellite images available to the public free of charge.

81 The spatial resolution ( $10 \mathrm{~m}$ is pixel) of the images is three times finer that of Landsat images,

82 thus increasing their potential for predicting and differentiating types of vegetation cover (Drush

83 et al., 2012; Borras et al., 2017). The Sentinel-2 has 13 bands, of which 10 provide greater-

84 quality radiometric images of spatial resolution 10 to $20 \mathrm{~m}$ in the visible and infrared regions of

85 the electromagnetic spectrum. These images are therefore ideal for land classification (ESA, 86 2017).

87 The aim of this research was i) to estimate the distribution of Pinus monophylla var. 88 californiarum in Sierra La Asamblea, Baja California (Mexico) by using Sentinel-2 images, and 89 ii) to test and describe the relationship between this distribution of $P$. monophylla and five 90 topographic and 18 climate variables. We hypothesized that i) the Sentinel-2 images can be used 91 to accurately predict the P. monophylla distribution in the study site due to finer resolution (x3) 92 and greater number of bands (x2) than in Landsat-8 data, and ii) the topographical variables 93 aspect, ruggedness and slope are particularly influential because they represent important 
94 microhabitat factors that can determine where conifers can become established and persist 95 (Marston, 2010).

\section{MATERIALS AND METHODS}

\section{Study area}

98 Sierra La Asamblea is located in Baja California's central desert (-114 ${ }^{\circ} 9^{\prime}$ W $29^{\circ} 19^{\prime} \mathrm{N}$, 99 elevation range $280-1,662 \mathrm{~m}$, Fig. 1). The climate in the area is arid, with maximum 100 temperatures of $40^{\circ} \mathrm{C}$ in the summer (Garcia, 1998). The sierra is steeper on the western slopes, 101 with an average incline of $35^{\circ}$, and with numerous canyons with occasional springs and oases. 102 Valleys and plateaus are common in the proximity of the Gulf of California. Granite rocks occur 103 south of the sierra and meta-sedimentary rocks along the north and southeast of the slopes. The 104 predominant type of vegetation is xerophilous scrub, which is distributed at elevations ranging 105 from 200 to $1,000 \mathrm{~m}$. Chaparral begins at an altitude of $800 \mathrm{~m}$, and representative specimens of 106 Adenostoma fasciculatum, Ambrosia ambrosioides, Dalea bicolor orcuttiana, Quercus 107 tuberculata, Juniperus california and Pinus monophylla are also present at elevations above $1081,000 \mathrm{~m}$. Populations of the endemic palm tree Brahea armata also occur in the lower parts of 109 the canyons with superficial water flow and through the rocky granite slopes (Bullock et al., 110 2006).

111 Figure 1. Map of Sierra La Asamblea. The black circles indicate georeferenced sites occupied by 112 Pinus monophylla. 


\section{Datasets}

\section{Sentinel-2}

116 The Sentinel-2A multispectral instrument (MSI) L1C dataset, acquired on 11 October 2016, in

117 the trajectory of coordinates latitude $29^{\circ} .814$, longitude $114^{\circ} .93$, was downloaded from the US.

118 Geological Survey (USGS) Global Visualization Viewer at http://glovis.usgs.gov/. The 12-bit

119 Sentinel-2A MSI image has 13 spectral bands in the visible, NIR, and SWIR wavelength regions

120 with spatial resolutions of 10-60 m. However, band one, used for studies of coastal aerosols, and

121 bands nine and ten, applied for respectively water vapour correction and cirrus detection, were

122 not used in this study (ESA, 2017). Hence, the data preparation involved four bands at $10 \mathrm{~m}$ and 123 the resampling of the six S2 bands acquired at $20 \mathrm{~m}$ to obtain a layer stack of 10 spectral bands at $12410 \mathrm{~m}$ (Table 1) using the ESA's Sentinel-toolbox ESA Sentinel Application Platform (SNAP) 125 and then converted to ENVI format.

126 Because atmospherically improved images are essential to enable assessment of spectral indices 127 with spatial reliability and product comparison, Level-1C data were converted to Level-2A 128 (Bottom of Atmosphere -BOA- reflectance) by taking into account the effects of aerosols and 129 water vapour on reflectance (Radoux et al., 2016). The corrections were made using the Sen2Cor 130 tool (Telespazio VEGA Deutschland GmbH, 2016) for Sentinel-2 images.

132 Table 1. Sentinel-2 spectral bands used to predict the Pinus monophylla forest cover 
134 The following equation was used to calculate the normalized difference vegetation index

135 (NDVI): NDVI $=(\mathrm{NIR}-\mathrm{R}) /(\mathrm{NIR}+\mathrm{R})$, where NIR is the near infrared light (band) reflected by

136 the vegetation, and $\mathrm{R}$ is the visible red light reflected by the vegetation (Rouse et al., 1974). The

137 NDVI is useful for discriminating the layers of temperate forest from scrub and chaparral. Areas

138 occupied by large amounts of unstressed green vegetation will have values much greater than 0

139 and areas with no vegetation will have values close to 0 and, in some cases, negative values

140 (Pettorelli, 2013). The NDVI image was combined with the previously described multi spectral

141 bands.

\section{Environmental variables}

143 Tree species distribution is generally modulated by hydroclimate and topographical variables

144 (Elliot et al., 2005; Decastilho et al., 2006), which can be estimated from digital terrain models

145 (DTM) (Osem et al., 2005; Spasojevic et al., 2016). A DTM was obtained by using tools

146 available from the Instituto Nacional de Estadistica y Geografía

147 (http:www.inegi.org.mx/geo/contenidos/datosrelieve) with a spatial resolution of $15 \mathrm{~m}$. The

148 DTM was processed with the QGIS (QGIS Development Team, 2016), using Terrain analysis

149 tools, elevation, slope and aspect (Table 2).

150 The ruggedness was estimated using two indexes: i) the terrain ruggedness index (TRI) of Riley

151 et al. (1999) and ii) a vector ruggedness measure (VRM), both implemented in QGIS (QGIS

152 Development Team, 2016). The TRI computes the values for each grid cell of a DEM. This

153 calculates the sum change in elevation between a grid cell and its eight-neighbor grid cell. VRM

154 incorporates the heterogeneity of both slope and aspect. This measure of ruggedness uses 3-

155 dimensional dispersion of vectors normal to planar facets on landscape. This index lacks units 
156 and ranges from 0 (indicating a totally flat area) to 1 (indicating maximum ruggedness)

157 (Sappington et al., 2007).

158 In addition, 18 climate variables with a 30-arc second resolution (approximate 800 meters)

159 (Table 2) were obtained from a national database managed by the University of Idaho 160 (http://charcoal.cnre.vt.edu/climate) and which requires point coordinates (latitude, longitude and 161 elevation) as the main inputs (Rehfeldt, 2006; Rehfeldt et al., 2006). These variables are

162 frequently used to study the potential effects of global warming on forests and plants in Western 163 North America and Mexico (Sáenz-Romero et al., 2010; Silva-Flores et al., 2014).

164 Table 2. Topographical and climatic variables considered in the study

\section{Pixel-based classification}

\section{Classification method}

168

169

170

171

172

173

174

175

Pixel-based classification was carried out in order to predict four different types of land cover in the study area (P. monophylla, scrub, chaparral and no apparent vegetation). A supervised classification approach with a backpropagation-type artificial neural network (BPNN) (Tan and Smeins, 1996) was applied. BPNN is widely used because of its structural simplicity and robustness in modelling non-linear relationships. In this study, the BPNN comprises a set of three layers (raster): an input layer, a hidden layer and an output layer (Richards, 1999). Each layer consists of a series of parallel processing elements (neurons or nodes). Each node in a layer is linked to all nodes in the next layer (Guo et al., 2013). 
176 The first step in BPNN supervised classification is to enter the input layer, which in this study

177 corresponded to the values of the pixels of ten Sentinel-2 bands and of the NDVI image. Weights

178 were then assigned to the BPNN to produce analytical predictions from the input values. These

179 data were contrasted with the category to which each training pixel belongs, corresponding to

180 Georeferenced sites (Datum WGS-84, 11N) obtained in the field in October 2014 and October 1812015.

182 A stratified random sampling method (Olofsson et al., 2013) was used to generate the reference 183 data in QGIS software (QGIS Development Team, 2016). A total of 2143 random points were 184 sampled, with at least 400 points for each class (Goodchild et al., 1994). The following classes 185 were considered: i) P. monophylla, 536 sites, ii) scrub, 764 sites, iii) chaparral, 405 sites, and iv) 186 no apparent vegetation, 438 sites. Class discrimination processes occurred in the hidden layer 187 and the synapses between the layers were estimated by an activation function. We used a logistic 188 function and training rate of 0.20 , previously applied to land cover classification (Hepner et al., 189 1990; Richards, 1999; Braspenning \& Thuijisman, 1995). Learning occurs by adjusting the 190 weights in the node to minimize the difference between the output node activation, and BPNN 191 then calculates the error at each iteration with root mean square error (RMS). The output layer 192 comprised four neurons representing the four target classes of land cover (P. monophylla, Scrub, 193 Chaparral and no apparent vegetation). Average spectral signatures for the four different types of 194 land cover are shown in Figure 2.

196 Figure 2. Average spectral signatures of cover vegetation in Sierra La Asamblea, Baja 197 California. 
199 The BPNN classification was cross-validated (10-fold) using a confusion matrix, which is a table 200 that compares the reference data and the classification results. We estimated the uncertainty of 201 the classification using estimated error matrix in terms of proportion of area and estimates of 202 overall map accuracy $(\hat{O})$, user's accuracy $\left(\hat{U}_{i}\right)$ (or commission error) and producer's accuracy $\left(\hat{P}_{j}\right.$ 203 ) (or omission error) recommended by Olofsson et al. (2013): $p_{i j}$ is defined as a cell entry of error 204 matrix of $i$ map classes. A poststratified estimator of $p_{i j}$ is:

$$
\hat{p}_{i j}=W_{i} \frac{n_{i j}}{n_{i}}
$$

where $W_{i}$ is the proportion of the area mapped as class $i . n_{i}$ is the total number of sample units in map class $i . n_{i j}$ is the sample count at cell $(i, j)$ in the error matrix. $\hat{p}_{. j}$ is a poststratified estimator for simple random and systematic sampling:

$$
\hat{p}_{. j}=\sum_{i=1}^{q} W_{i} \frac{n_{i j}}{n_{i .}}
$$

206 where $q$ is the class number.

207 An unbiased estimator of the total area of class $j$ is then

$$
\hat{A}_{j}=A \cdot \hat{p}_{. j}
$$

where $A$ is the total map area. For $\hat{p}_{. j}$, the standard error is estimated by:

$$
S\left(\hat{p}_{. j}\right)=\sqrt{\sum_{i=1}^{q} W_{i}^{2} \frac{\frac{n_{i j}}{n_{i .}}\left(1-\frac{n_{i j}}{n_{i .}}\right)}{n_{i .}-1}}
$$

The standard error of the error-adjusted estimated area is 


$$
S\left(\hat{A}_{j}\right)=A \cdot S\left(\hat{p}_{. j}\right)
$$

210 Finally,

$$
\hat{A}_{j} \pm 1.96 \cdot S\left(\hat{A}_{j}\right)
$$

211 presents an approximate $95 \%$ confidence interval.

212 The $\hat{O}, \hat{U}_{i}$ and $\hat{P}_{j}$ were calculated with Eqs. (7-9) (Congalton, 1991). $\hat{U}_{i}$ of class $i$ is the

213 proportion of the area mapped as class $i$ that has reference class $i . \hat{P}_{j}$ of class $j$ is the proportion

214 of the area of reference class $j$ that is mapped as class $j$.

$$
\begin{gathered}
\hat{O}=\sum_{j=1}^{q} \hat{p}_{j j} \\
\hat{U}_{i}=\frac{\hat{p}_{i i}}{\hat{p}_{i .}} \\
\hat{P}_{j}=\frac{\hat{p}_{j j}}{\hat{p}_{. j}}
\end{gathered}
$$

215 We then generated a map from the results of the probability of class assignment. The accuracy of 216 classification was also estimated using the Kappa $(K)$ coefficient. The $K$ coefficient is often used 217 as an overall measure of accuracy (Abraira, 2001). This coefficient takes values of between 0 218 and 1, where values close to one indicate a greater degree of agreement between classes and 219 observations, and a value of 0 suggests that the observed agreement is random. However, the use 220 of $K$ is controversial because i) $K$ would underestimate the probability that a randomly selected 221 pixel is correctly classified, ii) $K$ is greater correlated with overall accuracy so reporting Kappa is 222 redundant for overall accuracy (Olofsson et al., 2014). 


\section{Relationship between presence of $P$. monophylla and environmental variables}

224 To model and test the association between presence/absence of $P$. monophylla in the study area 225 and topographical or climate variables, a Kruskal-Wallis test was used to estimate the difference 226 in the median values in relation to presence and absence of $P$. monophylla. All variables for

227 which no significant difference between the median values was predicted after Bonferroni 228 correction $(\alpha=0.0005)$ were excluded from further analysis. The collinearity between the 229 variables with a significant difference between the medians of presence and absence was 230 estimated using the Spearman correlation coefficient $\left(r_{s}\right)$. When the $r_{s}$ value for the difference 231 between two variables was greater than 0.7 , only the variable with the lowest $p$ value in the 232 Kruskal-Wallis test was used in the models (as reported by Salas et al., 2017 and Shirk et al., 233 2018). Finally, stepwise multiple linear binominal logistical regression and Random Forest 234 classification including cross valuation (10-fold) were used to model the associations between 235 presence/absence of $P$. monophylla and the most important topographical and climate variables 236 (Shirk et al., 2018).

237 Regression and classification including cross-validations were carried out using the trainControl, 238 train, glm (family = "binomial") and rf functions, as well as the "randomForest" and "caret" 239 packages (Venables and Ripley, 2002) in R (version 3.3.2) (Development Core Team, 2017).

240 The goodness-of-fit of the logistical regression model was evaluated using the Akaike 241 information criterion (AIC), root-mean-square error (RMSE) and residual deviance. Validation 242 of the randomForest model was performed using under the curve (AUC; Fawcett, 2006), True 243 Skill Statistic (TSS; Allouche et al., 2006), Kappa (Abraira, 2001), specificity and sensitivity. 


\section{RESULTS}

\section{Pixel-based classification}

246 We estimated the area of $P$. monophylla cover with a margin of error (at approximate 95\%

247 confidence interval) of 6,653 \pm 319 (standard error) hectares in Sierra de la Asamblea, Baja 248 California, Mexico (Fig. 3). The confusion matrix of the accuracy assessment is listed in Table 3 249 including user's and producer's accuracy for each class. The supervised classification with 250 BPNN yielded predictions with an overall accuracy of identification of $87.74 \%$ (Table 4). This

251 level of accuracy was estimated in the 32 interactions with 0.04 RMS training. The proportion of 252 omission errors in the P. monophylla class was only $2.62 \%$, i.e. $97.39 \%$ of the pixels were 253 correctly classified. The shrub class had the larger proportion of omission errors (18.98\%). The 254 value of NDVI in the P. monophylla forest fluctuated between 0.30 and 0.41 , and in chaparral 255 between 0.24 and 0.28 . The smallest values of NDVI corresponded to scrub vegetation, with 256 values between 0.10 and 0.15 .

Figure 3. (A) Estimated land cover classes using BPNN classification in Sierra La Asambla. (B) Probability map of class assignment.

Table 3. Estimated error matrix based of sample counts $\left(n_{i j}\right)$ from the accuracy assessment sample. Map classes are the rows while the reference classes are the columns 
264 Table 4. Error matrix of four classes with cell entries $\left(p_{i j}\right)$ based on Table 3 and expressed in

265 terms of proportion of area. Accuracy measures are presented with a 95\% confidence interval.

266 Map classes (rows), reference classes (columns).

267

\section{Relationship between presence of $P$. monophylla and environmental variables}

269 The Kruskal-Wallis test indicated that the median values for ruggedness TRI $\left(\mathrm{p}<2.1 \times 10^{-16}\right)$, slope $\left(p<2.2 \times 10^{-16}\right)$, ruggedness VRM $\left(p=4.9 \times 10^{-9}\right)$, MTWM $(p=0.000014), \operatorname{MMAX}(p=$ 0.000048) and SPRP ( $p=0.00037)$ were most variable between sites in which P. monophylla was present and absent. The variable slope was closely correlated with ruggedness as well as with MMAX and MTWM $\left(r_{s}>0.7\right)$. The $p_{\text {slope }}$ of the Kruskal-Wallis test was larger than $p_{\text {ruggedness }}$ and $p_{M \text { MAX }}$ was larger than $p_{\text {MTWM. }}$ Slope and MMAX were therefore excluded from the model analysis. The stepwise multiple linear binominal logistical and Random Forest models

276 showed that the "presence of $P$. monophylla" model included the independent variables ruggedness, ruggedness VRM and average temperature in the warmest month (MTWM) (Table $278 \quad 5)$.

The ruggedness factor was the most influential predictor variable and indicated that the probability of $P$. monophylla occurrence was larger than $50 \%$ when the degree of ruggedness TRI was greater than $17.5 \mathrm{~m}$ (Table 5). The ruggedness VRM also indicated that a minimum change in roughness increases the probability of presence of the pine. The probability of occurrence of Pinus monophylla decreased when MTWM increased from 23.5 to $25.2^{\circ} \mathrm{C}$ (Table 5). After cross validation (10-fold), the Random Forest model revealed that the variables 
286 predict presence of the $P$. monophylla $(\mathrm{AUC}=0.920, \mathrm{TSS}=0.690, \mathrm{Kappa}=0.691)$. The 287 sensitivity was 0.812 and specificity was 0.878 .

288 Table 5. Results of the multiple linear binomial logistic regression model (AIC $=601.8$; residual 289 deviance $=593.85$ on 588 degrees of freedom), TRI $=$ terrain ruggedness index, VRM $=$ vector 290 ruggedness measure, $\mathrm{MTWM}=$ mean temperature in the warmest month.

\section{DISCUSSION}

\section{Pixel-based classification}

293 Predicting the presence of pine forest by using BPNN proved feasible. The NDVI was one of the variables that contributed to the prediction and clearly separated forest cover (NDVI $>0.35$ ) from the other types of vegetation cover (NDVI $<0.20)$. The overall accuracy of classification $(K=0.87)$ was similar to that reported in other studies using Sentinel-2A MSI images. For example, Immitzer et al. (2016) reported a $K$ of 0.85 for tree prediction in Europe by using five classes and a random forest classifier. Vieira et al. (2003) reported a $K=0.77$ in eastern Amazon using seven classes and 1999 Landsat 7 ETM imagery. However, Sothe et al. (2017) reported $K$ values of 0.98 and 0.90 for respectively three successional forest stages and field in a subtropical forest in Southern Brazil by using Sentinel-2 and Landsat-8 data associated with the support vector machine algorithm. Kun et al. (2014) estimated $K$ values of 0.70 to 0.85 for land-use type prediction (including forest) in China by using the support vector machine algorithm classifier and Landsat-8 images of rougher spatial resolution than Sentinel images. The very greater accuracy of predictions by Kun et al. (2014) was probably due to the large-scale of the study and the clearly differentiated types of land considered. 


\section{Relationship between presence of $P$. monophylla and environmental variables}

308 Ruggedness of the terrain was the most important topographic variable, significantly explaining 309 the presence of pines in Sierra La Asamblea (Table 5). Ruggedness, which is strongly positively 310 correlated with slope, may reduce solar radiation, air temperature and evapotranspiration due to 311 increased shading (Tsujino et al., 2006; Bullock et al., 2008). The ruggedness indicated by the

312 TRI index explains the presence of the pines because Sierra La Asamblea is heterogeneous in terms of elevation. The VRM index was less important partly because the index is strongly dependent on the vector aspect (Gisbert \& Martí, 2010) and in the case of Sierra Asamblea the aspect is very homogeneous and the index values therefore tend to be very low (Table 5), as also reported by $\mathrm{Wu}$ et al. (2018). The pines were expected to colonize north facing slopes, which are exposed to less solar radiation than slopes facing other directions. However, the topographical variable aspect was not important in determining the presence of $P$. monophylla var. californiarum in the study site, possibly because of physiological adaptations regarding wateruse efficiency and photosynthetic nitrogen-use efficiency (DeLucia \& Schlesinger, 1991), as reported for the Pinus monophylla, P. halepensis, $P$. edulis and P. remota in arid zones (Lanner \& Van Devender, 2000; Helman et al., 2017). The Mediterranean climate, with wet winters and dry summers, is another characteristic factor in this mountain range. In the winter in this part of the northern hemisphere, the sun (which is in a lower position and usually affects the southern aspect by radiation) is masked by clouds, rainfall and occasional snowfall (León-Portilla, 1988). During the summer, the solar radiation is more intense, but similar in all directions because the sun is closest to its highest point (Stage \& Salas, 2007).

The above-mentioned finding contrasts with those of other studies reporting that north-eastern facing slopes in the northern hemisphere receive less direct solar radiation, thus providing more 
330 favourable microclimatic conditions (air temperature, soil temperature, soil moisture) for forest

331 development, permanence and productivity than southwest-facing sites (Astrom et al., 2007;

332 Stage \& Salas, 2007; Hang et al 2009; Marston et al., 2010; Klein et al., 2014). DeLucia \&

333 Schleinger (1991) reported that P. monophylla populations in the Great Basin California desert

334 with summer rainfall (monsoon) preferred an east-southeast aspect with less intense solar 335 radiation and evapotranspiration.

336 The probability of occurrence of $P$. monophylla was also related to the climatic variable MTWM.

337 In Sierra La Asamblea, this pine species was found in a narrow range of MTWM of between $33823.5^{\circ}$ and $25.2^{\circ}$ (Table 1 ), which, however, is a smaller range than reported for the other pine 339 species (Tapias et al., 2004; Roberts \& Ezcurra, 2012). Therefore, this species should adapt well 340 to greater temperatures in the summer (Lanner et al., 2000), which is usually a very dry period in 341 the study site (León-Portilla, 1988). However, the probability of occurrence was greatest for an 342 MTWM of $23.5^{\circ} \mathrm{C}$ (Table 5), which occurred at the top of Sierra La Asamblea, at an elevation 343 of about $1,660 \mathrm{~m}$ ). We therefore conclude that this species can also grow well when the MTWM 344 is below $23.5^{\circ} \mathrm{C}$. On the other hand, considering MTWM as factor yielded a probability of 345 occurrence of $25-80 \%$. The spatial resolution of the climatic data by the national database run by 346 the University of Idaho is probably not adequate for describing the microhabitat of $P$. 347 monophylla (Rehfeldt et al., 2006; Marston et al., 2010).

348 Identification of the $P$. monophylla stands in Sierra La Asamblea as the most southern 349 populations represents an opportunity for research on climatic tolerance and community 350 responses to climatic variation and change. 


\section{ACKNOWLEDGEMENTS}

352 We are grateful to E. Espinoza, F. Macias and A. Guerrero for support with the fieldwork.

\section{REFERENCES}

354 Abraira V. 2001. El índice kappa. Semergen 27:247-249. DOI:10.1016/S1138- 3593(01)73955-X

355 Allen CD, Macalady AK, Chenchouni H, Bachelet D, Vennetier M, Kitzberger G, Rigling H, 356

Bailey DK. 1987. A study of Pinus subsection Cembroides. The single-needle pinyons of the Californias and the Great Basin. Notes from the Royal Botanic Garden, Edinburgh. 44:275310.

Borràs J, Delegido J, Pezzola A, Pereira M, Morassi G, Camps-Valls G. 2017. Land use classification from Sentinel-2 imagery. Revista de Teledetección 48:55-66. DOI: 10.4995/raet.2017.7133.

Braspenning P J, Thuijsman F. 1995. Artificial neural networks: an introduction to ANN theory and practice. Springer Science \& Business Media. USA. 295 p. 
371 Brockmann Consult, 2017. Sentinel Application Platform (SNAP). Available at: 372 http://step.esa.int/main. / (accessed 18 April 2017).

373 Bullock SH, Heath D. 2006. Growth rates and age of native palms in the Baja California desert. Journal of Arid Environments 67(3):391-402. DOI: 10.1016/j.jaridenv.2006.03.002.

Bullock SH, Salazar Ceseña JM, Rebman JP, Riemann H. 2008. Flora and vegetation of an isolated mountain range in the desert of Baja California. The Southwestern Naturalist 53:61-73. DOI: 10.1894/0038-4909(2008)53[61:FAVOAI]2.0.CO;2.

Callaway RM, DeLucia EH, Nowak R, Schlesinger WH. 1996. Competition and facilitation: contrasting effects of Artemisia tridentata on desert vs. montane pines. Ecology 77:21302141. DOI: $10.2307 / 2265707$.

Chambers JC. 2001. Pinus monophylla establishment in an expanding Pinus-Juniperus woodland: Environmental conditions, facilitation and interacting factors. Journal of Vegetation Science 12:27-40.

Cochran, W. G., 1977. Sampling techniques. New York, NY: Wiley.

CONABIO. 2017. Comisión Nacional para el Conocimiento y uso de la Biodiversidad. Geoportal de información. Sistema Nacional de información sobre Biodiversidad. Available at: http://www.conabio.gob.mx/informacion/gis/ (accessed 12 February 2017).

Congalton RG. 1991. A review of assessing the accuracy of classifications of remotely sensed data. Remote sensing of environment 37:35-46. DOI: 10.1016/0034-4257(91)90048-B 
390

391

392

393

394

395

396

397

398

399

400

401

402

403

404

405

406

407

408

409

DeCastilho CV, Magnusson WE, de Araújo RNO, Luizao RC, Luizao FJ, Lima AP, Higuchi N. 2006. Variation in aboveground tree live biomass in a central Amazonian Forest: Effects of soil and topography. Forest ecology and management 234:85-96. DOI: 10.1016/j.foreco.2006.06.024.

DeLucia, EH, \& Schlesinger, WH. 1991. Resource-use efficiency and drought tolerance in adjacent Great Basin and sierran plants. Ecology, 72(1), 51-58. DOI: 10.2307/1938901

Development Core Team. 2017. A language and environment for statistical computing. R foundation for statistical computing, Vienna Austria. Available at: http://www.Rproject.org. (accessed 8 September 2017).

Drusch M, Del Bello U, Carlier S, Colin O., Fernández V, Gascón F, Hoersch B, Isola C, Laberinti, P, Martimort P, Meygret A, Spoto F, Sy O, Marchese F, Bargellini P. 2012. Sentinel-2: ESA's Optical High-Resolution Mission for GMES Operational Services. Remote sensing environment 120:25-36. DOI: 10.1016/j.rse.2011.11.026.

Elliott KJ, Miniat CF, Pederson N, Laseter SH. 2005. Forest tree growth response to hydroclimate variability in the southern Appalachians. Global Change Biology 21(12):4627-4641. DOI: $10.1111 / \mathrm{gcb} .13045$.

ESA, 2017. European Space Agency. Copernicus, Sentinel-2. Available At: http://www.esa.int (accessed 21 March 2016).

Fawcett, T. 2006. An introduction to ROC analysis. Pattern Recognition Letters 27:861-874. DOI: $10.1016 /$ j.patrec.2005.10.010 
410 García E. 1998. Clasificación de Köppen, modificado por García, E. Comisión Nacional para el 411 Conocimiento y Uso de la Biodiversidad (CONABIO), 1998. Available at: 412 http://www.conabio.gob.mx/informacion/gis/ (accessed 2 June 2017).

413 Gisbert FJG, Martí IC. 2010. Un índice de rugosidad del terreno a escala municipal a partir de 414 Modelos de Elevación Digital de acceso público. Documento de Trabajo. Available at: 415 https://wheui3.grupobbva.com/TLFU/dat/DT_7_2010.pdf

416 Goodchild MF. 1994. Integrating GIS and remote sensing for vegetation analysis and modeling: methodological issues. Journal of Vegetation Science 5:615-626. DOI: 10.2307/3235878.

Guo PT, Wu W, Sheng QK, Li MF, Liu HB, Wang ZY. 2013. Prediction of soil organic matter using artificial neural network and topographic indicators in hilly areas. Nutrient cycling in agroecosystems 95:333344. DOI: 10.1007/s10705-013-9566-9.

Helman D, Osem Y, Yakir D, Lensky IM. 2017. Relationships between climate, topography, water use and productivity in two key Mediterranean forest types with different water-use strategies. Agricultural and Forest Meteorology 232:319-330. DOI: 10.1016/j.agrformet.2016.08.018.

Hepner G, Logan T, Ritter N, Bryant N. 1990. Artificial neural network classification using a minimal training set. Comparison to conventional supervised classification. Photogrammetric Engineering and Remote Sensing 56(4):469-473. 
428 Immitzer M,Vuolo F, Atzberger C. 2016. First Experience with Sentinel-2 Data for Crop and 429 Tree Species Classifications in Central Europe. Remote Sensing 8:1-27. DOI: 430 $10.3390 /$ rs 8030166.

431

432

433

434

435

436

437

438

439

440

441

442

443

444

445

446

INEGI. 2013. Conjunto de datos vectoriales de uso de suelo y vegetación escala 1:250 000, serie V. Instituto Nacional de Estadística y Geografía. Aguascalientes. Available at: http://www.conabio.gob.mx/informacion/gis/ (accessed 10 September 2015).

Klein T, Hoch G, Yakir D, Körner C. 2014. Drought stress, growth and nonstructural carbohydrate dynamics of pine trees in a semi-arid forest. Tree physiology 34:981-992. DOI: $10.1093 /$ treephys/tpu071.

Kun J, Xiangqin W, Xingfa G, Yunjun J. Xianhong X, Bin L. 2014. Land cover classification using Landsat 8 Operational Land Imager data in Beijing, China. Geocarto International 29:941-951. DOI:10.1080/10106049.2014.894586.

Lanner RM, Van Devender TR. 2000. The recent history of pinyon pines. In: Richardson, D. M. (eds). The American Southwest, Cambridge University Press. 171-182

Léon-Portilla. 1988. Miguel del Barco, Historia natural y crónica de la antigua California. Universidad Nacional Autónoma de México, México. 483 p.

Madonsela S, Cho MA., Ramoelo A, Mutanga O. 2017. Remote sensing of species diversity using Landsat 8 spectral variables. ISPRS Journal of Photogrammetry and Remote Sensing 133: 116-127. DOI: 10.1016/j.isprsjprs.2017.10.008. 
447 Marston, RA. 2010. Geomorphology and vegetation on hillslopes: interactions, dependencies, $448 \quad$ and feedback loops. Geomorphology, 116(3-4), 206-217.

449 Moran RV. 1983. Relictual northern plants on peninsular mountain tops. In: Biogeography of the 450 Sea of Cortez; University of California Press, Berkeley, USA. 408-410.

451 Olofsson O, Foody GM, Stehman SV, Woodcock CE. 2013. Making better use of accuracy data 452 in land change studies: Estimating accuracy and area and quantifying uncertainty using 453 stratified estimation. Remote Sensing of Environment 129:122-131. DOI: 10.1016/j.rse.2012.10.031

455

456

457

458

459

460

461

462

463

464

465

Olofsson, P, Foody, GM, Herold, M, Stehman, SV, Woodcock, CE, Wulder, MA. 2014. Good practices for estimating area and assessing accuracy of land change. Remote Sensing of Environment 148, 42-57. DOI: 10.1016/j.rse.2014.02.015

Osem Y, Zangy E, Bney-Moshe E., Moshe Y, Karni N, Nisan Y. 2009. The potential of transforming simple structured pine plantations into mixed Mediterranean forests through natural regeneration along a rainfall gradient. Forest Ecology Management 259:14-23. DOI:10.1016/j.foreco.2009.09.034.

Pettorelli N. 2013. The Normalized Difference Vegetation Index. Oxford, University Press. United Kingdom. 194 p.

QGIS Development, 2016. QGIS Geographic Information System. Open source Geospatial Foundation. Available at: http//qgis.osgeo.org 
466 Radoux J, Chomé G, Jacques DC, Waldner F, Bellemans N, Matton N, Lamarche C, 467 d'Andrimont R, Defourny P. 2016. Sentinel-2's potential for sub-pixel landscape feature 468 detection. Remote Sensing 8(6):488. DOI:10.3390/rs8060488.

469

470

471

472

473

474

475
Rehfeldt GE, 2006. A spline model of climate for the Western United States. Gen Tech Rep. RMRS-GTR-165. U.S. Department of Agriculture, Forest Service, Rocky Mountain Research Station, Fort Collins, Colorado, USA.

Rehfeldt GE, Crookston NL, Warwell MV, Evans JS. 2006. Empirical analyses of plant-climate relationships for the western United States. International journal plant science 167:11231150. DOI: 1058-5893/2006/16706-0005.

Richards JA. 1999. Remote Sensing Digital Image Analysis, Springer-Verlag, Berlin, p.240.

Riley SJ, Degloria SD, Elliot R. 1999. A terrain ruggedness index that quantifies topographic heterogeneity. Intermountain Journal of Sciences 5:23-27 (http://arcscripts.esri.com/details.asp?dbid=12435).

Roberts N, Ezcurra E. Desert Climate. 2012. In: Rebman, JP, Roberts NC, ed. Baja California Plant Field Guide. San Diego Natural History Museum. San Diego, USA. 1-23.

Rouse JW, Haas RH, Schell A, Deering DW. 1974. Monitoring vegetation systems in the Great Plains with ERTS. Proceedings of the Third Earth Resources Technology Satellite-1 Symposium, December 10-15 1974, Greenbelt, MD, NASA, Washington, DC, pp.301317. 
485 Sáenz-Romero C, Rehfeldt GE, Crookston NL, Duval P, St-Amant R, Beaulieu J, Richardson

486

487

488

489

490

491

492

493

494

495

496

497

498

499

500

501

502

503

504

BA. 2010. Spline models of contemporary, 2030, 2060 and 2090 climates for Mexico and their use in understanding climate-change impacts on the vegetation. Climatic Change, 102:595-623. DOI:10.1007/s10584-009-9753-5.

Salas EAL, Valdez R, Michel S. 2017. Summer and winter habitat suitability of Marco Polo argali in southeastern Tajikistan: A modeling approach. Heliyon 3(11):e00445. DOI:10.1016/j.heliyon.2017.e00445.

Sappington, JM., Longshore, KM., Thompson, D. B. 2007. Quantifying landscape ruggedness for animal habitat analysis: a case study using bighorn sheep in the Mojave Desert. Journal of wildlife management, 71(5):1419-1426. DOI: 10.2193/2005-723

Satage AR, Salas C. 2007. Interactions of Elevation, Aspect, and Slope in Models of Forest Species Composition and Productivity. Forest Science 53:486-492. Available at: http://www.ingentaconnect.com/

Silva-Flores R, Pérez-Verdín G, Wehenkel C. 2014. Patterns of tree species diversity in relation to climatic factors on the Sierra Madre Occidental, Mexico. PloS one 9, e105034. DOI: 10.1371/journal.pone.0105034.

Shirk AJ, Waring K, Cushman S, Wehenkel C, Leal-Sáenz A, Toney C, Lopez-Sanchez CA. 2017. Southwestern white pine (Pinus strobiformis) species distribution models predict large range shift and contraction due to climate change. Forest Ecology Management (in review). 
505 Sothe C, Almeida CMD, Liesenberg V, Schimalski MB. 2017. Evaluating Sentinel-2 and 506 Landsat-8 Data to Map Sucessional Forest Stages in a Subtropical Forest in Southern 507 Brazil. Remote Sensing 9(8):838. DOI:10.3390/rs9080838.

508 Spasojevic MJ, Bahlai CA, Bradley BA, Butterfield BJ, Tuanmu MN, Sistla S, Wiederholt R, 509 Suding KN. 2016. Scaling up the diversity-resilience relationship with trait databases and 510 remote sensing data: the recovery of productivity after wildfire. Global Change Biology 22(4):1421-1432. DOI: $10.1111 / \mathrm{gcb} .13174$.

512

513

514

515

516

517

518

519

520

521

522

523

524

Tan, S.S., Smeins, FE. 1996. Predicting grassland community changes with an artificial neural network model. Ecological Modelling 84(1-3): 91-97. DOI: /10.1016/0304-3800(94) 00131-6.

Tapias R, Climent J, Pardos JA, Gil L. 2004. Life histories of Mediterranean pines. Plant Ecology 171: 53-68. DOI:10.1023/B:VEGE.0000029383.72609.f0.

Telespazio VEGA Deutschland GmbH 2016. Sentinel-2 MSI-Level-2A. Prototype Processor Installation and User Manual. Available at: http://step.esa.int/thirdparties/sen2cor/2.2.1/S2PAD-VEGA-SUM-0001-2.2.pdf

Tsujino R, Takafumi H, Agetsuma N, Yumoto T. 2006. Variation in tree growth, mortality and recruitment among topographic positions in a warm temperate forest. Journal of Vegetation Science 17:281-290. DOI:10.1658/11009233(2006)17[281:VITGMA]2.0.CO;2. 
525 Venables WN, Ripley BD. 2002. Modern Applied Statistics with S-Plus. Fourth Edition. New $526 \quad$ York, Springer.

527 Vieira ICG, de Almeida AS, Davidson EA, Stone TA, de Carvalho CJR, Guerrero JB. 2003. 528 Classifying successional forests using Landsat spectral properties and ecological 529 characteristics in eastern Amazonia. Remote Sensing of Environment 87(4):470-481. 530 DOI:10.1016/j.rse.2002.09.002.

531 Wu W, Li AD, He XH, Ma R, Liu HB., Lv JK. 2018. A comparison of support vector machines, 532 artificial neural network and classification tree for identifying soil texture classes in 533 southwest China. Computers and Electronics in Agriculture 144:86-93. DOI: $534 \quad$ 10.1016/j.compag.2017.11.037. 
Figure 1

Map of Sierra La Asamblea.

The black circles indicate georeferenced sites occupied by Pinus monophylla.

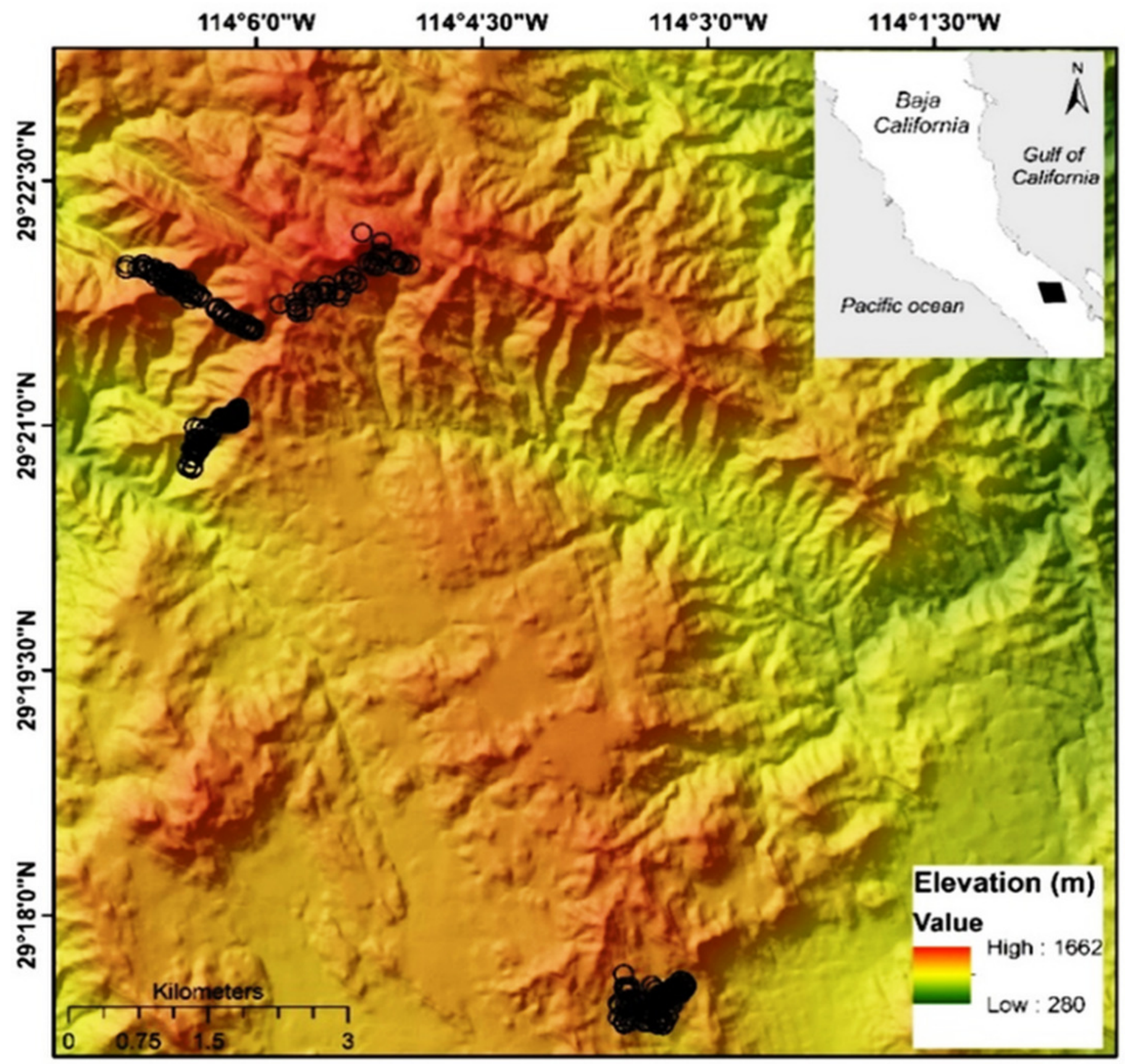


Figure 2

Average spectral signatures of cover vegetation in Sierra La Asamblea, Baja California.

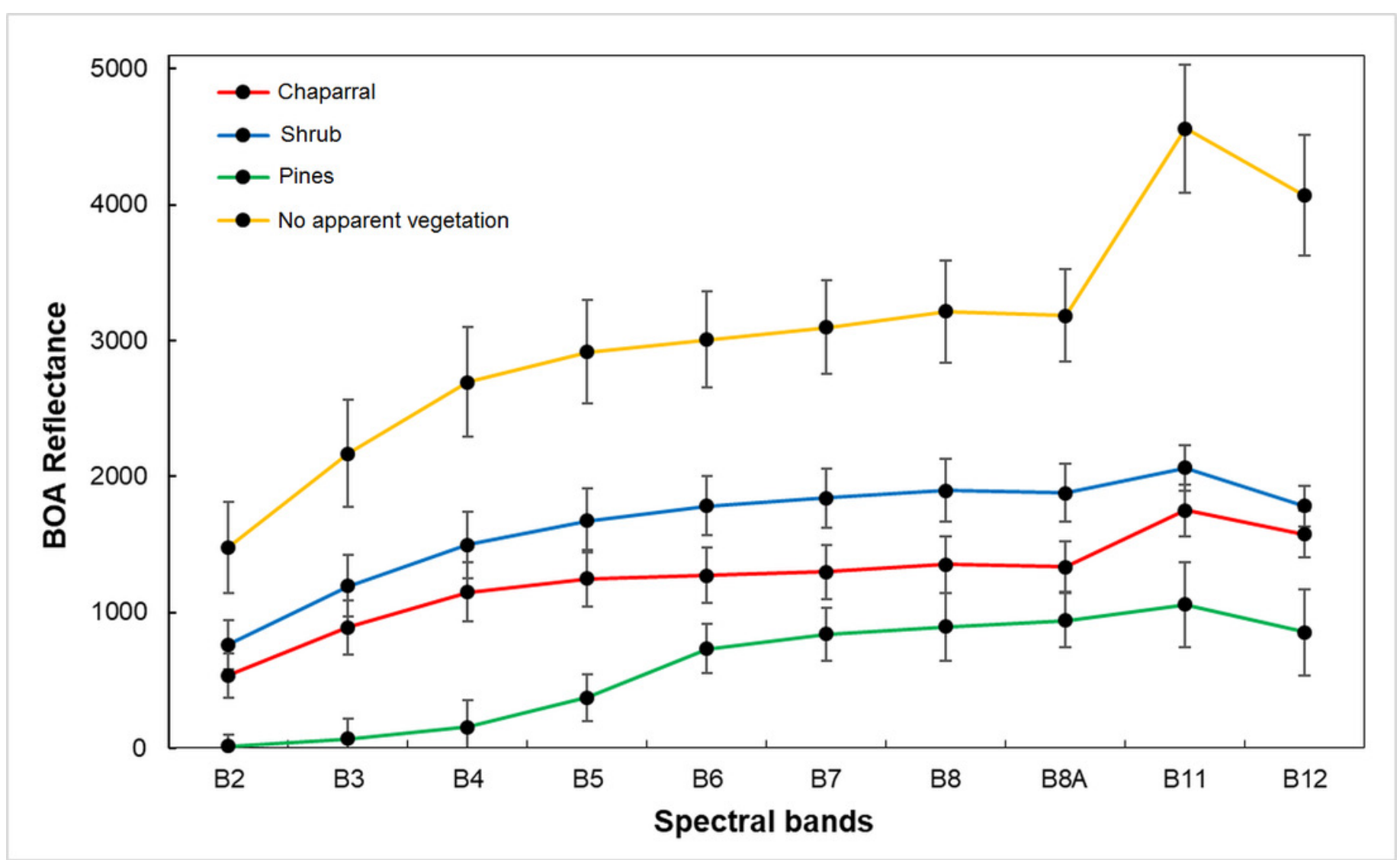


Figure 3

(A) Estimated land cover classes using BPNN classification in Sierra La Asambla. (B) Probability map of class assignment.
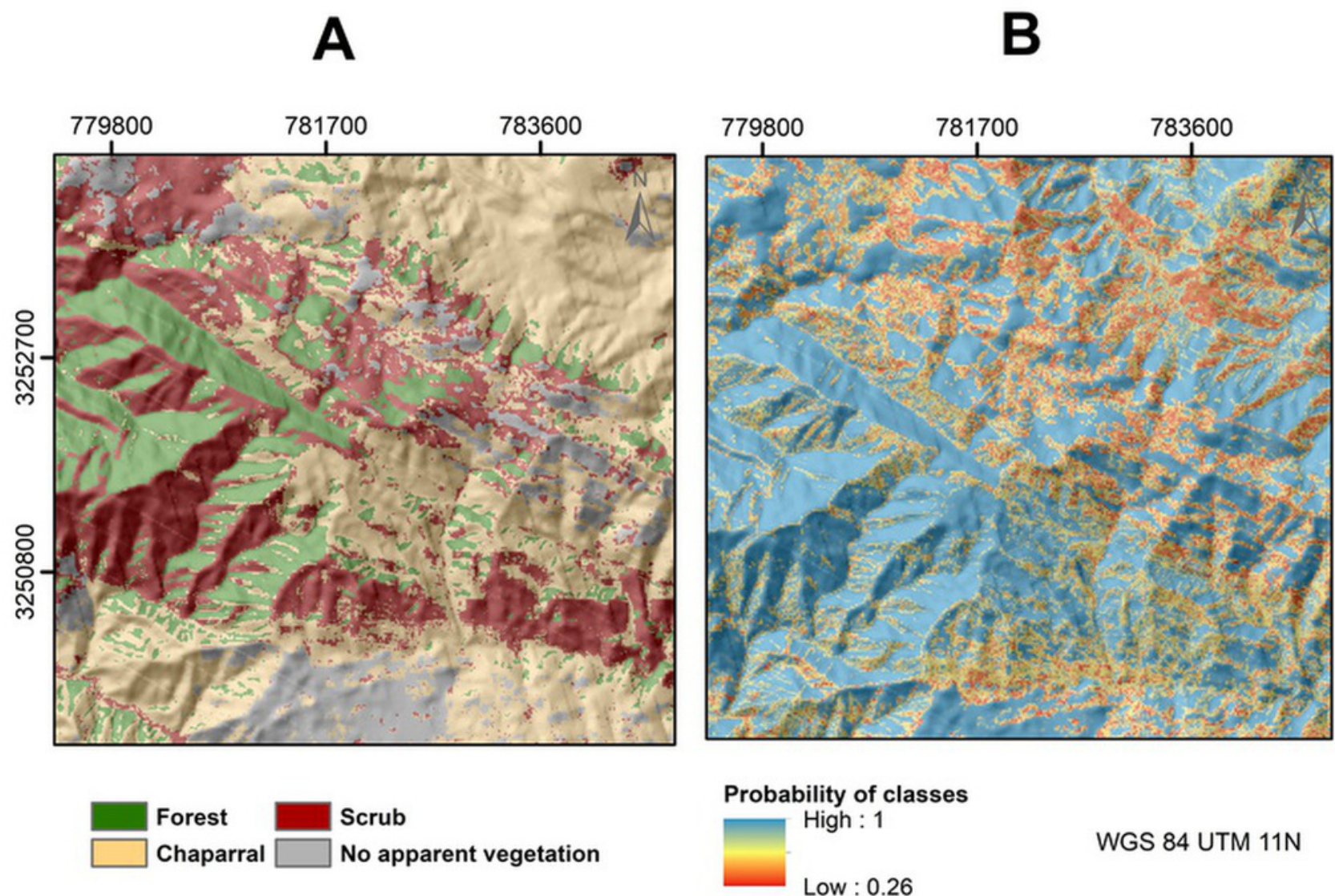

Probability of classes

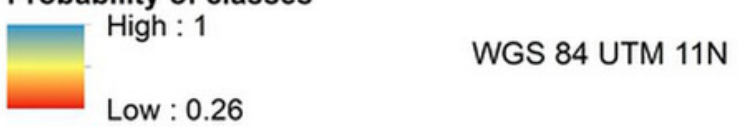




\section{Table 1 (on next page)}

Sentinel-2 spectral bands used to predict the Pinus monophylla forest cover. 


\begin{tabular}{lcc}
\hline \multicolumn{1}{c}{ Band } & Central wavelength $(\boldsymbol{\mu m})$ & Resolution $(\mathbf{m})$ \\
\hline Band 2-Blue & 0.490 & 10 \\
\hline Band 3 - Green & 0.560 & 10 \\
\hline Band 4 - Red & 0.665 & 10 \\
\hline Band 5- Vegetation red edge & 0.705 & 20 \\
\hline Band 6- Vegetation red edge & 0.740 & 20 \\
\hline Band 7- Vegetation red edge & 0.783 & 20 \\
\hline Band 8- NIR & 0.842 & 10 \\
\hline Band 8A- Vegetation red edge & 0.865 & 20 \\
\hline Band 11 -SWIR & 1.610 & 20 \\
\hline Band 12 -SWIR & 2.190 & 20 \\
\hline
\end{tabular}

1 


\section{Table 2 (on next page)}

Topographical and climatic variables considered in the study. 


\begin{tabular}{|c|c|c|c|c|c|c|}
\hline Variable & Abbreviation & Units & Mean & $\mathrm{SD}$ & Max & Min \\
\hline Ruggedness & IRT & $\mathrm{m}$ & 20.33 & 6.66 & 35.90 & 4.69 \\
\hline Ruggedness VRM & VRM & NA & 0.005 & 0.007 & 0.13 & 0 \\
\hline Slope & $\mathrm{S}$ & o & 28.38 & 8.92 & 48.34 & 3.42 \\
\hline Aspect * & $\mathrm{A}$ & o & 190.51 & 68.72 & 350.44 & 20.55 \\
\hline Elevation * & $\mathrm{E}$ & $\mathrm{m}$ & 1302.41 & 124.96 & 1631 & 1010 \\
\hline Mean annual temperature $*$ & MAT & ${ }^{\circ} \mathrm{C}$ & 16.57 & 0.38 & 17.4 & 15.5 \\
\hline Mean annual precipitation * & MAP & $\mathrm{mm}$ & 229.56 & 19.95 & 288 & 184 \\
\hline $\begin{array}{l}\text { Growing season precipitation, April- } \\
\text { September * }\end{array}$ & GSP & $\mathrm{mm}$ & 79.08 & 9.60 & 108 & 57 \\
\hline $\begin{array}{l}\text { Mean temperature in the coldest } \\
\text { month * }\end{array}$ & MTCM & ${ }^{\circ} \mathrm{C}$ & 10.85 & 0.37 & 11.7 & 9.8 \\
\hline $\begin{array}{l}\text { Minimum temperature in the coldest } \\
\text { month * }\end{array}$ & MMIN & ${ }^{\circ} \mathrm{C}$ & 3.42 & 0.41 & 4.3 & 2.3 \\
\hline $\begin{array}{l}\text { Mean temperature in the warmest } \\
\text { month }\end{array}$ & MTWM & ${ }^{\circ} \mathrm{C}$ & 24.52 & 0.31 & 25.2 & 23.5 \\
\hline $\begin{array}{l}\text { Maximum temperature in the } \\
\text { warmest month }\end{array}$ & MMAX & ${ }^{\circ} \mathrm{C}$ & 34.10 & 0.31 & 34.7 & 33.1 \\
\hline $\begin{array}{l}\text { Julian date of the last freezing data of } \\
\text { spring * }\end{array}$ & SDAY & Days & 82.57 & 7.86 & 106 & 60 \\
\hline $\begin{array}{l}\text { Julian date of the first freezing data of } \\
\text { autumn * }\end{array}$ & FDAY & Days & 331.28 & 2.62 & 339 & 324 \\
\hline Length of the frost-free period $*$ & FFP & Days & 259.22 & 8.36 & 285 & 240 \\
\hline Degree days $>5^{\circ} \mathrm{C} *$ & DD5 & Days & 4245.26 & 137.52 & 4550 & 3852 \\
\hline $\begin{array}{l}\text { Degree days }>5^{\circ} \mathrm{C} \text { accumulating } \\
\text { within the frost-free period } *\end{array}$ & GSDD5 & Days & 3491.82 & 164.76 & 3944 & 2995 \\
\hline $\begin{array}{l}\text { Julian date when the sum degree days } \\
>5^{\circ} \mathrm{C} \text { reaches } 100 *\end{array}$ & D100 & Days & 17.07 & 1.10 & 20 & 15 \\
\hline Degree days $<0{ }^{\circ} \mathrm{C} *$ & DD0 & Days & 0 & 0 & 0 & 0 \\
\hline Minimum degree days $<0{ }^{\circ} \mathrm{C} *$ & MMINDD0 & Days & 8.07 & 20.29 & 145 & 45 \\
\hline Spring precipitation & Sprp & $\mathrm{mm}$ & 7.54 & 0.71 & 10 & 6 \\
\hline Summer precipitation * & Smrp & $\mathrm{mm}$ & 43.74 & 6.29 & 62 & 29 \\
\hline Winter precipitation $*$ & Winp & $\mathrm{mm}$ & 110.93 & 7.93 & 133 & 93 \\
\hline
\end{tabular}

1

$2 *$ Variables for which no significant difference between the medians was obtained after

3 Bonferroni correction $(\alpha=0.0005)$ were excluded from further analysis. 


\section{Table 3(on next page)}

Estimated error matrix based of sample counts $\left(n_{i j}\right)$ from the accuracy assessment sample.

Map classes are the rows while the reference classes are the columns. 
1

\begin{tabular}{|c|c|c|c|c|c|c|c|c|}
\hline & \multirow[b]{2}{*}{ Classes* } & \multicolumn{4}{|c|}{ Reference } & \multirow{2}{*}{ Total } & \multirow{2}{*}{$\begin{array}{c}\text { Map area } \\
\text { (ha) }\end{array}$} & \multirow{2}{*}{$W_{i}$} \\
\hline & & $\mathbf{P}$ & $\mathbf{S}$ & C & WV & & & \\
\hline \multirow{5}{*}{ Map } & $\mathbf{P}$ & 522 & 0 & 14 & 0 & 536 & 5,395 & 0.169 \\
\hline & $\mathbf{S}$ & 24 & 619 & 119 & 2 & 764 & 12,309 & 0.387 \\
\hline & $\mathbf{C}$ & 50 & 0 & 348 & 7 & 405 & 8,206 & 0.258 \\
\hline & WV & 0 & 0 & 20 & 418 & 438 & 5,913 & 0.186 \\
\hline & Total & 596 & 619 & 501 & 427 & 2,143 & 31,823 & 1 \\
\hline
\end{tabular}

2 * Classes: $\mathrm{P}=$ Pinus monophylla; $\mathrm{S}=$ shrub; $\mathrm{C}=$ chaparral; $\mathrm{WV}=$ without vegetation; $W_{i}=$ 3 proportion of the area mapped as class $i$. 


\section{Table 4 (on next page)}

Error matrix of four classes with cell entries $\left(p_{i j}\right)$ based on Table 3 and expressed in terms of proportion of area.

Accuracy measures are presented with a $95 \%$ confidence interval. Map classes (rows), reference classes (columns). 


\begin{tabular}{ccccccccc}
\hline & \multicolumn{9}{c}{ References } & \multicolumn{3}{c}{ Accuracy } \\
\hline \multirow{2}{*}{ Classes } & $\mathbf{P}$ & $\mathbf{S}$ & $\mathbf{C}$ & $\mathbf{W V}$ & User's & Producer's & Overall \\
\hline \multirow{3}{*}{ Map } & & 0.1651 & 0.0000 & 0.0044 & 0.0000 & $0.970 \pm 0.07$ & $0.790 \pm 0.04$ & $0.877 \pm 0.01$ \\
\cline { 2 - 9 } & $\mathbf{S}$ & 0.0122 & 0.3134 & 0.0602 & 0.0010 & $0.810 \pm 0.02$ & 1.000 & \\
\cline { 2 - 9 } & $\mathbf{C}$ & 0.0318 & 0.0000 & 0.2216 & 0.0045 & $0.859 \pm 0.01$ & $0.752 \pm 0.07$ & \\
\cline { 2 - 9 } & $\mathbf{W V}$ & 0.0000 & 0.0000 & 0.0085 & 0.1773 & $0.954 \pm 0.002$ & $0.970 \pm 0.02$ & \\
\cline { 2 - 9 } & Total & 0.2091 & 0.3134 & 0.2947 & 0.1828 & & & \\
\hline
\end{tabular}

1 * Classes: $\mathrm{P}=$ Pinus monophylla $\mathrm{S}=$ shrub; $\mathrm{C}=$ chaparral; $\mathrm{WV}=$ without vegetation. 


\section{Table 5 (on next page)}

Results of the multiple linear binomial logistic regression model ( $\mathrm{AIC}=601.8$; residual deviance $=593.85$ on 588 degrees of freedom), TRI = terrain ruggedness index, VRM = vector ruggedness measure, MTWM = mean temperature in the warmest month. 
1

\begin{tabular}{ccccc}
\hline Variable & Estimate & Std. Error & Z value & Pr $(>|\mathbf{z}|)$ \\
\hline Intercept & 25.351 & 8.895 & 2.850 & 0.0044 \\
\hline MTWM & -1.159 & 0.362 & -3.201 & 0.0014 \\
\hline Roughness TRI & 0.178 & 0.015 & 11.200 & $<2 \mathrm{e}-16$ \\
\hline Roughness VRM & 28.476 & 13.847 & 2.056 & 0.0397 \\
\hline
\end{tabular}

2

3

4 